Eur. J. Clin. Chem. Clin. Biochem.

Vol. 29, 1991, pp. 819-826

(C) 1991 Walter de Gruyter \& Co. Berlin - New York

\title{
Application of a New Monoclonal Antibody for Time-resolved Fluoroimmunoassay of Human Pancreatic Phospholipase $\mathrm{A}_{2}$
}

By S. Aulikki Santavuori ${ }^{1}$, Pirjo T. Kortesuo ${ }^{2}$, Jarkko U. Eskola ${ }^{3}$ and Timo J. Nevalainen ${ }^{2}$

${ }^{1}$ Labmaster Ltd., Turku, Finland

2 Department of Pathology, University of Turku, Turku, Finland

${ }^{3}$ The Joint Clinical Biochemistry Laboratory of University of Turku, Turku University Central Hospital and Wallac Ltd., Turku, Finland

(Received June 4/October 17, 1991)

Summary: A monoclonal antibody, designated 2E1, against human pancreatic phospholipase $A_{2}$ was produced by hybridization of myeloma cells with spleen cells of immunized BALB/c mice. The hybridomas were screened for antibody production by time-resolved fluoroimmunoassay (TR-FIA). The antibody was found to belong to subclass I of murine IgG. The specificity of the antibody was confirmed by immunohistochemistry of pancreatic and other tissues, by immunoblotting of a crude aqueous extract of human pancreas and purified human pancreatic phospholipase $A_{2}$ and by TR-FIA. A solid-phase time-resolved fluoroimmunoassay was developed by using the monoclonal anti-phospholipase $\mathrm{A}_{2}$ antibody as the catching antibody and a polyclonal sheep anti-phospholipase $A_{2}$ antibody labelled with europium as the detecting antibody. The validity of the new TR-FIA of human pancreatic phospholipase $A_{2}$ was confirmed by using it to measure the phospholipase $A_{2}$ concentrations in serum samples from healthy subjects and from patients suffering from acute pancreatitis.

\section{Introduction}

Pancreatic phospholipase $A_{2}{ }^{1}$ ) is a digestive enzyme synthesized by pancreatic acinar cells and secreted as an enzymatically inactive proenzyme into the duodenum, where it is transformed into an active form by limited hydrolysis by trypsin. Only two immunochemical techniquess for measuring the concentration of pancreatic phospholipase $A_{2}$ in serum and other body fluids have been developed. These methods are based on either time-resolved fluoroimmunoassay (TR-FIA) (1) or radioimmunoassay (RIA), $(2,3)$, and employ polyclonal anti-phospholipase $\mathrm{A}_{2}$ antibodies raised in rabbits. An RIA-method employing a monoclonal antibody was described recently (4). Increased values of immunoreactive pancreatic phospholipase $\mathrm{A}_{2}$ have been found in sera of patients suffering from acute pancreatitis $(5,6)$, pancreatic cancer (5) and

\section{1) Enzymes:}

Phospholipase $\mathrm{A}_{2}$, phosphatide 2-acylhydrolase (EC 3.1.1.4) other malignant tumours of various types (4). The increased concentration of immunoreactive pancreatic phospholipase $A_{2}$ in serum is a sensitive indicator of acinar cell damage in acute pancreatitis and other pancreatic injuries (5). In patients with liver, gall bladder and pancreatic cancer, the elevation of serum phospholipase $\mathrm{A}_{2}$ correlated with the stage of the disease (4).

The purpose of the present study was to prepare monoclonal antibodies against human pancreatic secretory phospholipase $A_{2}$, to test their specificity and to develop a new immunoassay for the measurement of the phospholipase $A_{2}$ concentration in serum. Time-resolved fluorescence was used as a detecting method in a solid-phase sandwich assay. The monoclonal antibody was used as the catching antibody and polyclonal anti-phospholipase $\mathrm{A}_{2}$ antibody labelled with an europium (Eu) chelate was used as the detecting antibody. 


\section{Materials and Methods}

\section{Reagents}

Fetal calf serum was purchased from Gibco Laboratories, Grand Island NY., USA. Hypoxanthine-aminopterin-thymidine concentrate, Pristane and Freund's adjuvant were from Sigma, St. Louis MO., USA. Hypoxanthine-thymidine concentrate was from Flow Laboratories, Irvine, Scotland. KC 2000 medium was from Hazleton Biologics, St. Lenexa, KS., USA. The europium chelate for labelling the anti-phospholipase $A_{2}$ antibody was from Wallac, Turku, Finland. Affi-gel Protein A MAPS II kit was from Bio-Rad Laboratories, Richmond CA., USA and Serotec Isotyping Kit for monoclonal antibodies from Serotec, Oxford, England. NS-1 myeloma cell line was obtained from the Department of Virology, University of Turku, Turku, Finland. Rabbit anti-mouse immunoglobulins were from Dakopatts, Glostrup, Denmark. Vectastain ABC-kit and ABC-APkit for immunostaining procedures were from Vector Laboratories, Burlingame, CA., USA and nitrocellulose from Millipore, Molsheim, France. Activated CH-Sepharose 4B and Sephadex G50 were from Pharmacia, Uppsala, Sweden. Trisacryl GF2000 gel was from IBF, Villeneuve-la-Garenne, France. Microtitre plates used in TR-FIA measurements were from Eflab, Helsinki, Finland. Porcine pancreatic phospholipase $\mathrm{A}_{2}$ and bee venom phospholipase $A_{2}$ were from Sigma, St. Louis MO. USA. Human ascitic phospholipase $A_{2}$ was purified from cellfree ascitic fluid from patients suffering from ovarian carcinoma and peritoneal carcinosis, as described earlier (7). Rat pancreatic phospholipase $A_{2}$ was purified by a method described earlier (8) from pancreases of Wistar rats (Kortesuo, P., Hietaranta, A. \& Nevalainen, T., to be published).

\section{Solutions and buffers}

The TR-FIA assay buffer and the enhancement solution were from Wallac, Turku, Finland. Tris/saline/azide buffer consisted of $50 \mathrm{mmol}$ Tris- $\mathrm{HCl} \mathrm{pH} 7.75$ containing $9 \mathrm{~g}$ of $\mathrm{NaCl}$ and $5 \mathrm{~g}$ of $\mathrm{NaN}_{3}$ per litre. Microtitre plates were washed with a solution containing $9 \mathrm{~g}$ of $\mathrm{NaCl}, 0.2 \mathrm{~g}$ of $\mathrm{NaN}_{3}$ and $1 \mathrm{~g}$ of Tween 20 per litre. The saturation solution consisted of Tris/saline/azide buffer containing $1 \mathrm{~g}$ of bovine serum albumin, $60 \mathrm{~g}$ of $D$ sorbitol, $111 \mathrm{mg} \mathrm{CaCl}$ (anhydrous) and $39.3 \mathrm{mg}$ diethylenetriaminepentaacetate (DTPA, Titriplex V) per litre. All chemicals used were of analytical grade.

\section{Standards}

Human pancreatic phospholipase $\dot{A}_{2}$ stock solution was diluted with TR-FIA assay buffer to give four standard concentrations $1.5,9.0,54$ and $324 \mu \mathrm{g} / \mathrm{l}$.

\section{Serum samples}

Sera for the determination of the normal reference interval of immunoreactive pancreatic phospholipase $\mathrm{A}_{2}$ were obtained from 57 healthy volunteers ( 23 women and $34 \mathrm{men}$ ). The average age was 41 years (range 20-64). Serum samples were also obtained from 39 patients suffering from acute pancreatitis, 7 women and 32 men, average age 64 years (range $52-85$ ) and 42 years (range $23-69$ ), respectively. The diagnosis of acute pancreatitis was based on clinical presentation (abdominal pain, nausea, vomiting), radiological (CT-scan) findings and elevated serum and/or urinary amylase concentration, and on operative findings in 14 patients. The aetiology was biliary disease in 5 , alcohol in 31 and unknown in 3 patients. All sera were stored at $-20^{\circ} \mathrm{C}$ until assayed.

\section{Apparatus}

Microtitre plates were washed in a 12-well aspirating-washing device (Wellwash 4) and incubation in an automated shaking device (Wellmix 3) from Denley, Billingham, England. Fluorescence was measured with an Arcus fluorometer, Wallac, Turku, Finland. Electrophoresis was performed with a PhastSystem ${ }^{\text {TM }}$ apparatus, Pharmacia, Uppsala, Sweden.

\section{Purification of human pancreatic phospholipase $\mathbf{A}_{2}$}

Phospholipase $A_{2}$ was purified from human cadaver pancreas as described earlier (8).

Preparation of antibodies to human pancreatic phospholipase $\mathrm{A}_{2}$

Monoclonal antibodies were produced according to the method of Galfre \& Milstein (9). Briefly, male mice (BALB/cKuo, from the University of Kuopio, Kuopio, Finland) were immunized three times at two-week intervals subcutaneously with $50 \mu \mathrm{g}$ of purified human pancreatic phospholipase $A_{2}$. For the first immunization, the antigen was mixed with complete Freund's adjuvant $(1+1$ by vol.) and for the second and third immunizations with incomplete Freund's adjuvant. After the third immunization, the animals were bled and tested by TR-FIA for specific antibody. The animal that showed the highest antibody response against phospholipase $\mathrm{A}_{2}$ at serum dilution $1: 100$ was boosted intravenously via the tail vein with $100 \mu \mathrm{g}$ of antigen in $100 \mu$ of saline. Three days after the booster injection, the mouse was killed and its spleen cells were harvested and fused with mouse myeloma cells (NS-1) by treatment with $500 \mathrm{ml} / 1$ PEG 4000 in KC 2000-medium containing 200 $\mathrm{ml} / \mathrm{l}$ fetal calf serum. The fused cells were cultured in hypoxanthine-aminopterin-thymidine medium supplemented with 200 $\mathrm{ml} / \mathrm{l}$ fetal calf serum until myeloma cells disappeared, after which they were cultured in hypoxanthine-thymidine medium supplemented with $200 \mathrm{ml} / \mathrm{l}$ fetal calf serum. Hybridoma supernatants were tested for antibody production by TR-FIA. Positive cells were cloned two times by the limiting dilution method. Finally the resulting hybridomas were injected into the peritoneal cavity of $\mathrm{BALB} / \mathrm{c}$ mice pretreated with pristane to obtain monoclonal antibodies in the ascitic fluid.

Antiserum to human pancreatic phospholipase $A_{2}$ wäs raised in a sheep. The sheep was immunized three times at three-week intervals subcutaneously with $0.1 \mathrm{mg}$ of purified phospholipase $\mathrm{A}_{2}$ in Freund's complete adjuivant: Serum was collected two weeks after the last booster injection.

The immunoglobulin subclass of the monoclonal antibody was determined in hybridoma supernatants with the Serotec Isotyping kit for monoclonal antibodies according to the manufacturer's instructions.

\section{Purification of antibodies}

Polyclonal sheep antibodies were purified by passing the antiserum through an affinity column containing human pancreatic phospholipase $A_{2}$ coupled to $C H$-Sepharose $4 B$ as a ligand. The coupling of protein to the gel was performed according to the manufacturer's instructions. The specific anti-phospholipase $\mathrm{A}_{2}$ antibody was eluted with $7.5 \mathrm{~mol} / \mathrm{l}$ sodium thiocyanate in phosphate buffer (pH 7.3).

The monoclonal antibody was purified by affinity chromatography with the Protein A MAPS II kit.

\section{Electrophoresis and immunoblotting}

The specificity of the monoclonal antibody was determined by immunoblotting of purified human pancreatic phospholipase $A_{2}$ and a crude aqueous extract of human pancreas after ammonium sulphate precipitation (8). Electrophoresis was performed on SDS-PAGE $8-25 \%$ gradient gel with the PhastSystem $^{\mathrm{TM}}$ apparatus according to the manufacturer's instruci 
tions. Proteins were visualized by Coomassie blue staining. Proteins were transferred to nitrocellulose filters with the PhastSystem semidry immunoblotting device according to the manufacturer's instructions. The Vectastain ABC-kit was used for the immunostaining of the nitrocellulose filters.

\section{Immunohistochemistry}

Samples of human pancreas and various other tissues were from the files of the Department of Pathology, University of Turku, Turku, Finland. The tissues were fixed in buffered formalin, embedded in paraffin, and sectioned at $5 \mu \mathrm{m}$. The immunostaining was performed by using the monoclonal antibody $2 \mathrm{E} 1$ as the primary antibody and a Vectastain $\mathrm{ABC}$ (avidinbiotin complex) kit for detecting the site of the immunoreaction according to the manufacturer's instructions. In control stainings, the primary antibody was replaced by either bovine serum albumin or a non-related monoclonal antibody (anti-IgE antibody).

\section{Labelling of phospholipase $A_{2}$ antibody}

The affinity-purified sheep anti-phospholipase $A_{2}$ antibody was labelled with an isothiocyanate derivative of the europium chelate $\left(\mathrm{Eu}^{3+}-\mathrm{N}^{1}-(p\right.$-isothiocyanatobenzyl)-diethylene-triamine$N^{1}, N^{2}, N^{3}, N^{3}$-tetraacetate) as described earlier $(1,10)$. The europium chelate at 53-fold molar excess was allowed to react with the affinity purified antibody. The $\mathrm{pH}$ was adjusted to 9.5 with $1 \mathrm{~mol} / 1 \mathrm{Na}_{2} \mathrm{CO}_{3}$ solution. After an overnight incubation at $4{ }^{\circ} \mathrm{C}$, the labelled antibody was separated from excess reagent by gel filtration through a column $1.8 \mathrm{~cm}$ in diameter and filled with Trisacryl GF2000 to a height of $37 \mathrm{~cm}$ with an additional $9 \mathrm{~cm}$ of Sephadex G50 on top. The column was eluted with 50 $\mathrm{mmol} / \mathrm{l}$ Tris/saline/azide buffer. About 9 moles of Eu were incorporated per mole of immunoglobulin.

\section{Coating of polystyrene microtitre plates}

Microtitre plates made of polystyrene were coated with the monoclonal anti-phospholipase $A_{2}$ antibody $(25 \mathrm{mg} / \mathrm{l})$ by physical adsorption from $0.2 \mathrm{ml}$ of Tris/saline/azide buffer overnight. The plates were washed two times in an automatic washing device before use.

\section{Time-resolved fluoroimmunoassays}

Measurements with TR-FIA were performed as described earlier (1). Serum samples of immunized mice and hybridoma supernatants were tested in microtitre plates coated with affinity-purified polyclonal anti-phospholipase $A_{2}$ antiserum $(1 \mu \mathrm{g}$ contained in $100 \mu$ ladded to each well). The coated plates were washed four times, after which either $5 \mathrm{ng}(100 \mu \mathrm{l} /$ well) of purified pancreatic phospholipase $A_{2}$ (positive tests) or $100 \mu$ l of assay buffer (negative tests) were pipetted into the wells. After incubation for $1 \mathrm{~h}$ and washing, $30 \mu \mathrm{l}$ of serum dilution or hybridoma growth medium with $70 \mu \mathrm{l}$ assay buffer were added. Positive cells were detected with $100 \mathrm{ng}(100 \mu \mathrm{l} /$ well $)$ of Eu-labelled rabbit antibodies to mouse IgG.

For the TR-FIA of human pancreatic phospholipase $A_{2}, 25 \mu$ l of serum sample or human phospholipase $A_{2}$ standard in TRFIA assay buffer were pipetted into the microtitre wells, which had been coated with monoclonal anti-phospholipase $A_{2}$ antibody and contained $175 \mu$ l of TR-FIA assay buffer. After $1 \mathrm{~h}$ incubation with shaking at room temperature, the wells were aspirated and washed six times, and the Eu-labelled polyclonal anti-phospholipase $A_{2}$ antibody ( $500 \mathrm{ng} /$ well) was added. The washing step was repeated after $1 \mathrm{~h}$ and $200 \mu \mathrm{l}$ of enbancement solution was added. After 5 minutes shaking and 10 minutes standing, fluorescence was measured with an Arcus fluorometer.
For the TR-FIA of human pancreatic phospholipase $A_{2}$ employing only polyclonal anti-phospholipase $\mathrm{A}_{2}$ antibodies, the microtitre wells were coated with affinity-purified polyclonal sheep anti-phospholipase $A_{2}$ antibody $(5 \mu \mathrm{g} / 200 \mu \mathrm{l}$ per well) by physical adsorption overnight. Otherwise the assay procedure was the same as described above.

\section{Statistics}

The ninety five per cent reference interval was calculated according to the recommendations of the International Federation of Clinical Chemistry (11). The Refval statistical analysis system ( $H$. Solberg, Department of Clinical Chemistry, Rikshospitalet, Oslo, Norway) software package was used for the statistical analysis and calculation of the reference interval on a microcomputer.

\section{Results}

Monoclonal antibody 2E1 against human pancreatic phospholipase $A_{2}$

One of the hybridomas, 2E1, produced an antibody that specifically reacted with human pancreatic phospholipase $\mathrm{A}_{2}$. The purity of the monoclonal antibody 2E1 after the affinity purification with MAPS II Kit was verified by SDS-PAGE, where it gave homogeneous protein bands with relative molecular masses of approximately 62000 (heavy chain) and 25000 (light chain). The subclass of the monoclonal antibody 2E1 was identified as IgG1.

The specificities of monoclonal and polyclonal antibodies were determined by immunohistochemistry and immunoblotting. An aqueous extract of human pancreas and purified pancreatic phospholipase $\mathrm{A}_{2}$ were resolved by SDS-PAGE, blotted to a nitrocellulose membrane and stained with monoclonal and polyclonal antibodies. The monoclonal antibody $2 \mathrm{E} 1$ reacted with one protein band only in both cases. The antibody 2E1 recognized the non-reduced native form but not the reduced form of the human pancreatic phospholipase $A_{2}$ enzyme (fig. 1). The polyclonal sheep anti-phospholipase $A_{2}$ antiserum gave one protein band with purified human pancreatic phospholipase $\mathrm{A}_{2}$ (fig. 1). It recognized, however, one major band of apparent $M_{\mathrm{r}}$ about 15000 and another weak band of higher $M_{\mathrm{r}}$ in the aqueous extract of human pancreas (fig. 1). Phospholipase $A_{2}$ was found in the cytoplasm of pancreatic acinar cells by immunohistochemistry using the monoclonal antibody 2E1 (fig. 2). No reaction was seen in pancreatic duct cells or islets of Langerhans or in other human tissues studied (liver, kidney, spleen, muscle, lymph node and thyroid). The specificity of the monoclonal antibody $2 \mathrm{E} 1$ was also investigated by TR-FIA (fig. 3). The antibody reacted with human, rat and porcine pancreatic phospholipase $A_{2}$ but not with bee venom phospholipase $A_{2}$ or phospholipase $A_{2}$ purified from human ascitic fluid. 
A

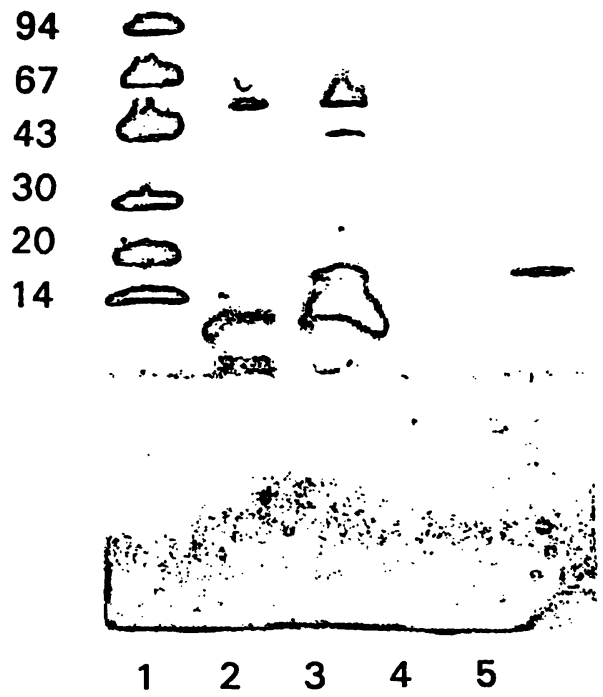

B

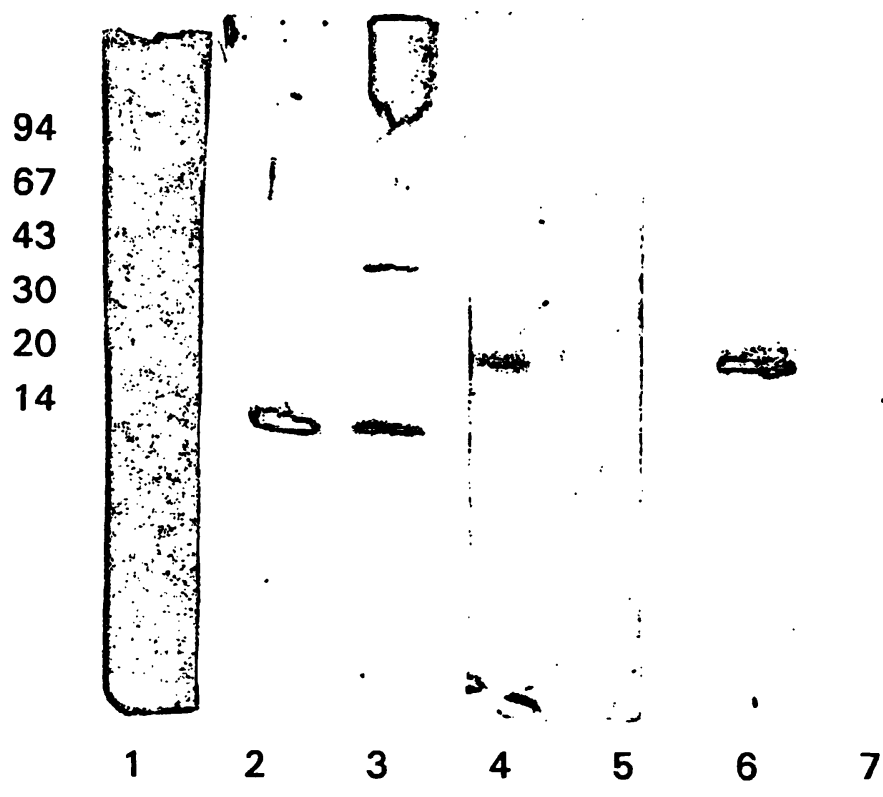

Fig. 1. SDS-PAGE electrophoresis (a) and immunoblotting (b) of an aqueous extract of human pancreas and purified pancreatic phospholipase $A_{2}$.

a) SDS-PAGE was carried out as described in the section "Methods".

1. Molecular weight standards $\left(M_{\mathrm{r}} 14400-94000\right)$.

2. Non-reduced pancreatic extract.

3. Reduced pancreatic extract.

4. Purified pancreatic phospholipase $A_{2}$, non-reduced.

5. Purified pancreatic phospholipase $A_{2}$, reduced.

b) Detection of pancreatic phospholipase $A_{2}$ by immunoblotting performed as described in the section "Methods".

1. Molecular weight standards $\left(M_{\mathrm{r}} 14400-94000\right)$.

2. Purified pancreatic phospholipase $\mathrm{A}_{2}$.

3. Pancreatic extract. Phospholipase $A_{2}$ in lanes 2 and 3 was detected with the polyclonal sheep anti-phospholipase $A_{2}$ antiserum.

4. Non-reduced pancreatic extract.

5. Reduced pancreatic extract. Phospholipase $A_{2}$ in lanes 4 and 5 was detected with the monoclonal antiphospholipase $\mathrm{A}_{2}$ antibody $2 \mathrm{E} 1$.

6. Purified pancreatic phospholipase $A_{2}$, non-reduced.

7. Purified pancreatic phospholipase $A_{2}$, reduced. Phospholipase $A_{2}$ in lanes 6 and 7 was detected with the monoclonal antibody $2 \mathrm{E} 1$.

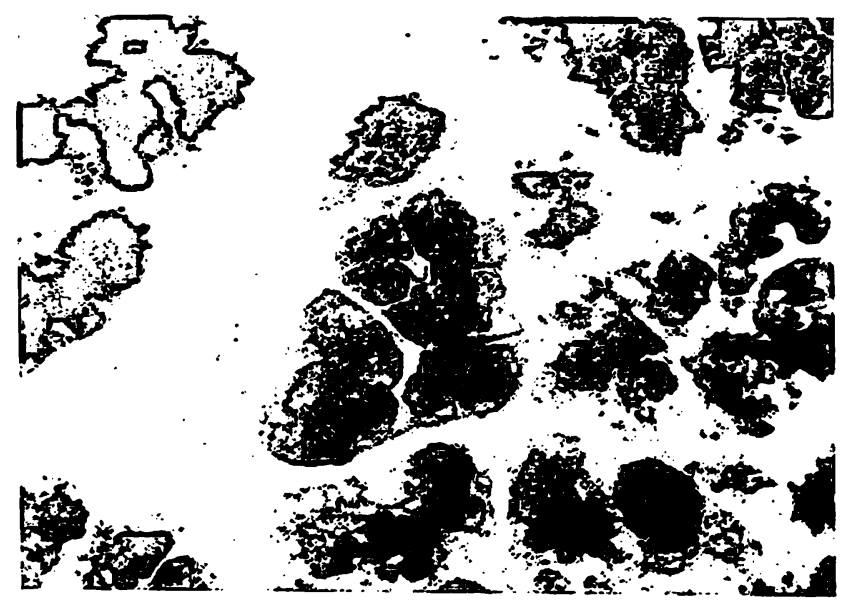

Fig. 2. Immunohistochemical localization of phospholipase $A_{2}$ in human pancreas. A formalin-fixed, paraffin-embedded tissue section stained with affinity purified monoclonal antibody $2 \mathrm{E} 1(1.46 \mathrm{mg} / \mathrm{l})$, avidin-biotin-complex method (ABC). Acinar cells contain immunoreactive material - Magnification 430x.

$$
\text { .: }
$$

Eur. J. Clin. Chem. Clin. Biochem. / Vol. 29, 1991 / No. 12 


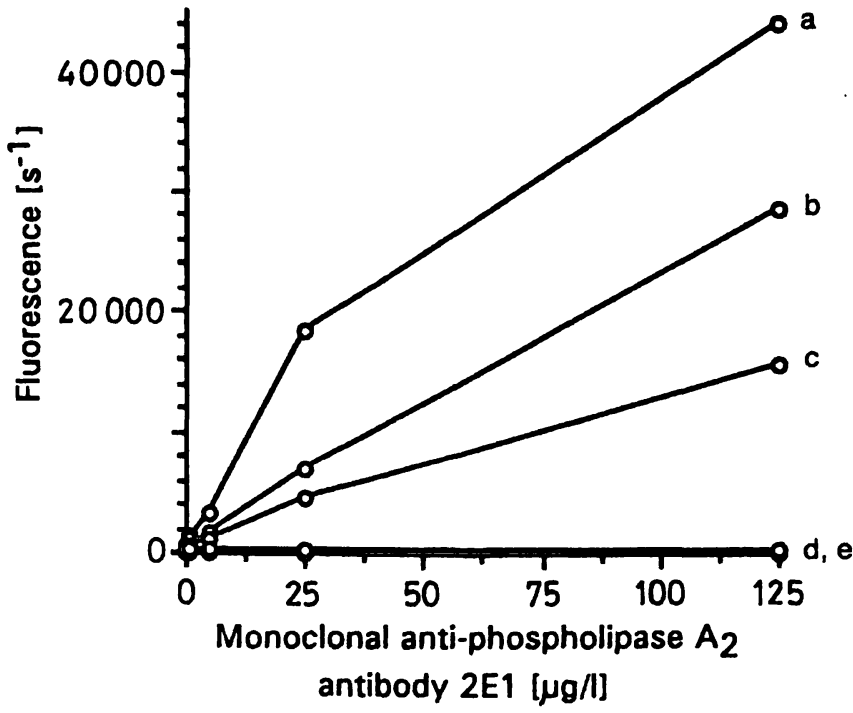

Fig. 3. Specific binding of monoclonal anti-phospholipase $A_{2}$ antibody $2 E 1$ to pancreatic phospholipase $A_{2}$ as determined by TR-FIA.

Microtitre plates were coated with $1 \mathrm{ng} /$ well of phospholipase $A_{2}$ purified from

a) human pancreas

b) rat pancreas

c) porcine pancreas

d) bee venom and

e) human ascitic fluid.

After saturation with a saturation solution and incubation with the monoclonal antibody 2E1, the immunoreaction was detected with an Eu-labelled rabbit antimouse IgG second antibody. There is considerable cross-reactivity between human, rat and porcine pancreatic phospholipase $\mathrm{A}_{2} \mathrm{~S}$, but none between human pancreatic and ascitic fluid or bee venom phospholipase $\mathrm{A}_{2} \mathrm{~s}$.

TR-FIA for human pancreatic phospholipase $\mathrm{A}_{2}$

Standard curve, precision profile, detection limit and assay range

The standard curve for TR-FIA of human phospholipase $A_{2}$ and the precision profile calculated from 12 replicates (one strip) for each phospholipase $A_{2}$ concentration are shown in figure 4 . The coefficient of intraassay variation ranged from 2.8 to $9.9 \%$. The sensitivity of the assay defined as equivalent to the concentration corresponding to the mean fluorescence of zero standard ( 12 replicates) plus twice the standard deviation was determined to be $0.28 \mu \mathrm{g} / \mathrm{l}$. The range of values that can be measured with this method is $0.28-324 \mu \mathrm{g} / \mathrm{l}$.

\section{Analytical recovery}

Two different concentrations $(20,150 \mu \mathrm{g} / \mathrm{l})$ of human phospholipase $A_{2}$ standards were added to five serum samples with'starting phospholipase $A_{2}$ values varying from 4.11 to $28.49 \mu \mathrm{g} / \mathrm{l}$. The percentage recovery of phospholipase $A_{2}$ was calculated as (amount found

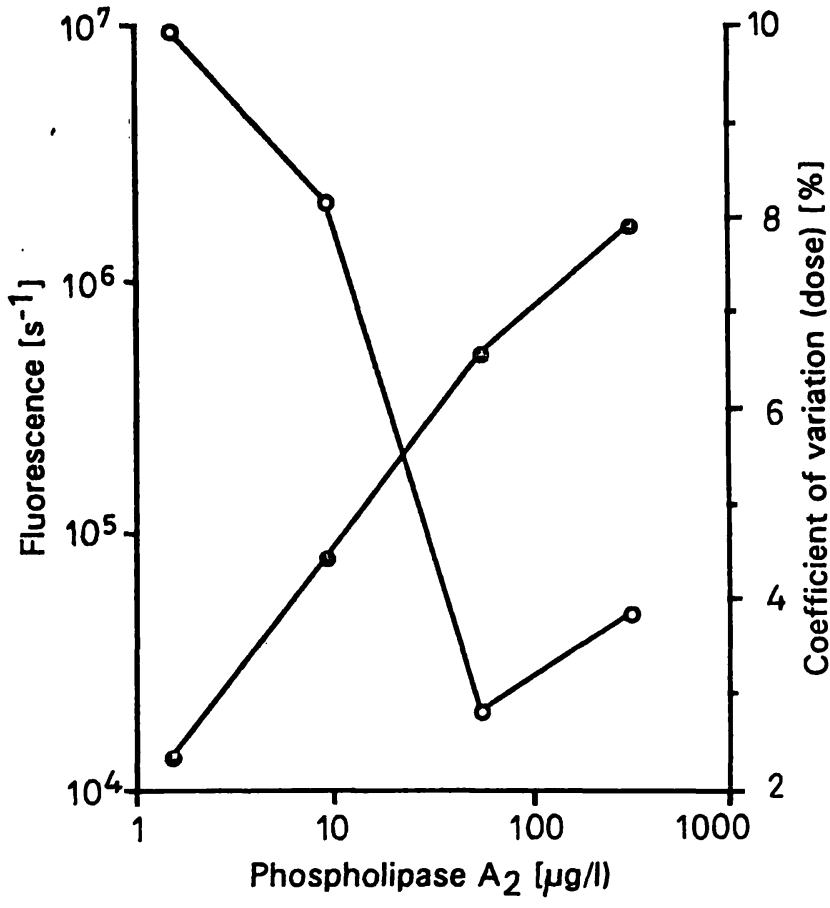

Fig. 4. Dose-response curve (0) and precision profile (O) for the TR-FIA of human pancreatic phospholipase $A_{2}$.

of added phospholipase $\mathrm{A}_{2}$ /amount phospholipase $\mathrm{A}_{2}$ added ) $\times 100$. The analytical recoveries were $96.2 \%$ and $123.1 \%$, respectively, with an overall mean $109.6 \%$

\section{Linearity}

Four serum samples containing different concentrations of phospholipase $A_{2}(92.81,18.07,15.21$ and $4.33 \mu \mathrm{g} / \mathrm{l})$ were diluted serially with assay buffer and analysed by TR-FIA. Excellent correlations ( $r=0.99,1.00,1.00$ and 0.99 , respectively) were found in all four cases.

\section{Reference interval}

The mean concentration of phospholipase $A_{2}$ in the serum of 57 apparently healthy individuals (23 women, 34 men) was $5.8 \mu \mathrm{g} / \mathrm{l}$ (SD 1.4). Given the parametric distribution of this analyte, the $95 \%$ reference interval was $3.1-9.0 \mu \mathrm{g} / \mathrm{l}$.

\section{Inter-method comparison}

For comparison with a TR-FIA method using polyclonal sheep anti-phospholipase $A_{2}$ antibodies, the concentration of phospholipase $A_{2}$ in 67 sera (28 normal, 39 pancreatitis) was measured by both the TR-FIA methods. The new assay was found to correlate well with the comparison method. The results were: $y=0.803 x+3.24 ; r=0.95, n=67$ (fig. 6 ). 


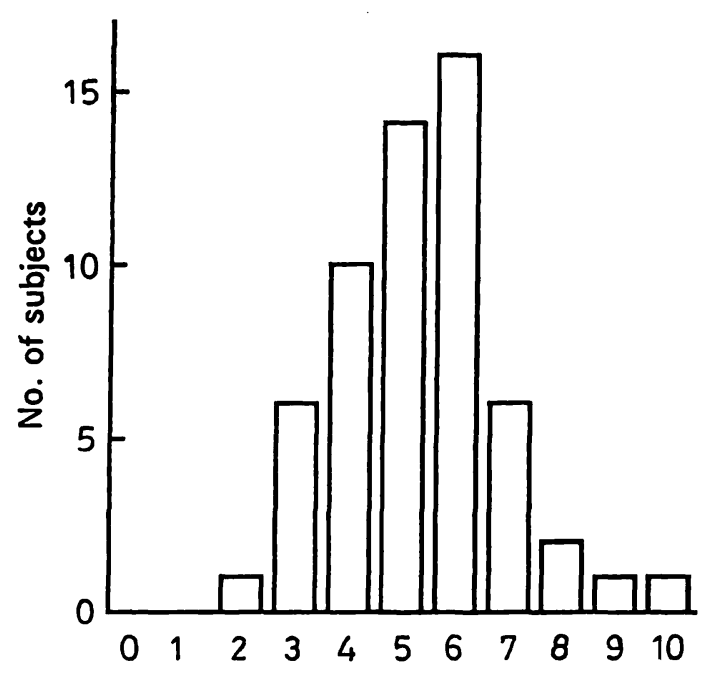

Immunoreactive phospholipase $A_{2}[\mu \mathrm{g} /]$

Fig. 5. Distribution of values of pancreatic phospholipase $A_{2}$ in sera of 23 healthy women and 34 men.

The mean age was 41 years (range 20-64). The mean concentration of phospholipase $A_{2}$ is $5.8 \pm 1.4 \mu \mathrm{g} / \mathrm{l}$.

\section{Discussion}

Phospholipase $\mathrm{A}_{2}$ exists either as an extracellular secretory enzyme or as an intracellular enzyme. The bee and snake venom and pancreatic secretory phospholipases $A_{2}$ are typical extracellular enzymes. Intracellular phospholipases $A_{2}$ have been described in many cell types, and they exist either in soluble form in the cytosol, or they are membrane-bound in various subcellular compartments (12-15). Membrane-associated and soluble phospholipases $\mathrm{A}_{2}$ differ in their substrate specificity (14) and hydrophobic properties (15), and they may also be functionally distinct. Membrane-bound phospholipases $\mathrm{A}_{2}$ are believed to participate in the regulation of phospholipid metabolism in biomembranes including the biosynthesis of eicosanoids and the acylation-deacylation cycle of phospholipids (12).

Antibodies have been used to investigate immunochemical and structural relationships between phospholipases $\mathrm{A}_{2}$ from different sources. There are only limited and somewhat contradictory data on the antigenic relationship between intracellular and extracellular phospholipases $\mathrm{A}_{2}$. A polyclonal antiserum against human pancreatic phospholipase $A_{2}$ did not recognize snake venom phospholipases $A_{2}(16)$ or seminal fluid phospholipase $\mathrm{A}_{2}$ (17). Okamoto et al. (18) found immunological similarity between rat pancreatic phospholipase $\mathrm{A}_{2}$ and rat splenic microsomal phospholipase $\mathbf{A}_{2}$. A monoclonal antibody against rat liver mitochondrial phospholipase $\mathrm{A}_{2}$ reacted with rat

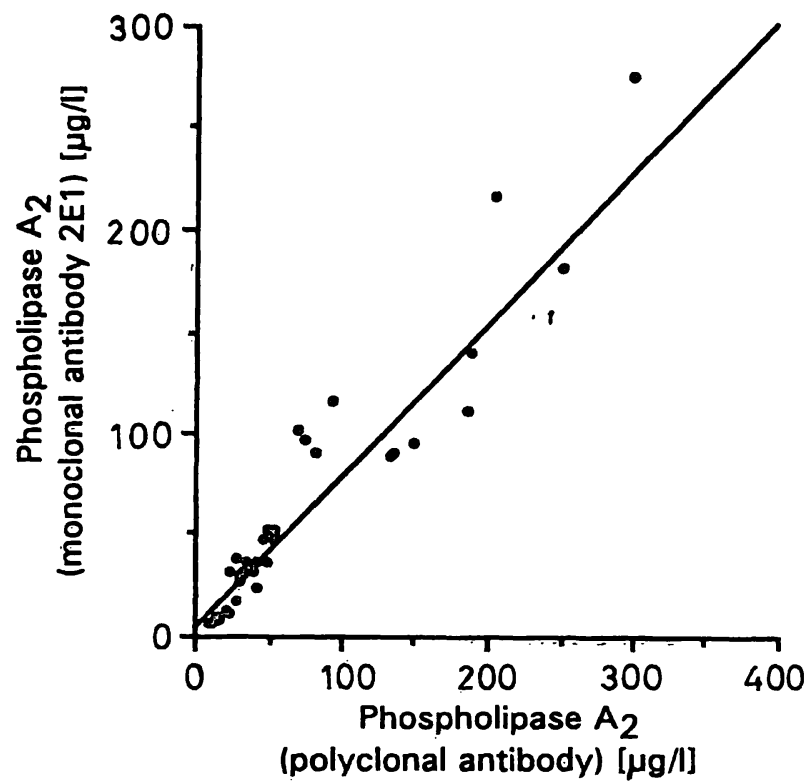

Fig. 6. Correlation between two TR-FIA methods using either sheep polyclonal or mouse monoclonal 2E1 anti-phospholipase $\mathrm{A}_{2}$ antibody as the catching antibody. Pancreatic phospholipase $A_{2}$ concentrations were assayed in serum samples of healthy individuals $(n=28)$ and patients suffering from acute pancreatitis $(n=39)$. The linear regression equation is $y=0.803 x+3.24$; $\mathrm{r}=0.95, \mathrm{n}=67$.

liver cytosol and rat platelet phospholipase $A_{2}$ but did not recognize rat or pig pancreatic phospholipase $A_{2}$ or snake venom phospholipase $\mathrm{A}_{2}$ (19). Mollier et al. (20) prepared a monoclonal antibody against monomeric phospholipase $A_{2}$ from snake venoms, and found that the antibody recognized phospholipase $A_{2}$ from snake venoms but not from bee venom, porcine pancreas, rat lymphocytes or guinea pig alveolar macrophages. Masliah et al. (21) demonstrated antigenic similarity between an extracellular phospholipase $A_{2}$ (Naja naja venom) and membrane-bound phospholipase $A_{2}$ from two different mammalian species and cell types (guinea pig alveolar macrophages and rat lymphocytes). In immunohistochemistry, the present monoclonal antibody 2E1 was found to be specific to pancreatic phospholipase $A_{2}$. Immunoreactivity was found in human pancreatic acinar cells but not in other human tissues. We also investigated by TR-FIA the cross-reactivity of the monoclonal antibody 2E1 with non-pancreatic phospholipases $\mathrm{A}_{2}$ (bee venom and human ascitic fluid phospholipase $A_{2}$ ) and found no cross-reactivity. However, we found definite crossreactivity with pancratic phospholipases $\mathrm{A}_{2}$ from other mammalian species. The antibody $2 \mathrm{E} 1$ reacted with rat and porcine pancreatic phospholipase $A_{2}$, but it showed the highest affinity for human pancratic phospholipase $\mathrm{A}_{2}$. This finding confirms earlier observations that phospholipases $\mathrm{A}_{2}$ from human, rat and porcine pancreas are closely related antigenically $(2,22)$. 
In the present study we developed a TR-FIA for the measurement of human pancreatic phospholipase $A_{2}$ based on the new monoclonal antibody $2 E 1$, the latter being used as the catching antibody in a solid-phase assay. The increased concentration of immunoreactive pancreatic phospholipase $A_{2}$ in serum is a specific and sensitive marker of acinar cell injury that occurs e.g. in acute pancreatitis. In our earlier study, we found increased serum phospholipase $A_{2}$ concentrations invariably at the early stages of both mild and severe forms of acute pancratitis (5). The phospholipase $A_{2}$ values were found to return to the reference interval at a somewhat slower rate than corresponding amylase activities in acute pancreatitis. The immunoreactive phospholipase $A_{2}$ may include the active enzyme, the enzymatically inactive proenzyme and/or degraded fragments of the active enzyme that may be catalytically active or inactive. Therefore immunoassays do not give any information as to the catalytic activity of the phospholipase $A_{2}$ enzyme molecule being measured. Since the catalytic activity of phospholipase $A_{2}$ correlates with the severity of the disease in acute pancratitis (6), it is advisible to measure both the catalytic activity of phospholipase $A_{2}$ and the concentration of immunoreactive pancreatic phospholipase $A_{2}$ in the same serum samples in order to specifically detect pancreatic acinar cell injury (by the latter method) and to assess the severity of the disease process (by the former method). There is an ample selection of methods available for the determination of phospholipase $A_{2}$ catalytic activity (23).

The previously reported radioimmunoassays and the TR-FIA for measuring the concentration of human immunoreactive pancreatic phospholipase $\mathrm{A}_{2}$ employ polyclonal antibodies raised in rabbits $(1-3,5)$. The use of a monoclonal instead of a polyclonal antibody, however, would offer the advantage of unlimited supply, constant and predictable quality, and high specificity. Recently another RIA-method for the determination of pancreatic phospholipase $A_{2}$ employing a monoclonal antibody was described (4).

The mean $( \pm S D)$ phospholipase $A_{2}$ value, $5.8 \pm 1.4$ $\mu \mathrm{g} / \mathrm{l}$, measured in sera of healthy individuals by the present TR-FIA agrees well with the phospholipase $A_{2}$ concentrations found by different immunoassays (RIA, TR-FIA): $6.5 \pm 2.0 \mu \mathrm{g} / \mathrm{l}$ (serum, 1), $5.1 \pm 1.7$ $\mu \mathrm{g} / \mathrm{l}$ (serum, 2), $4.3 \pm 1.3 \mu \mathrm{g} / \mathrm{l}$ (plasma, 3), $2.4 \pm 0.69$ $\mu \mathrm{g} / \mathrm{l}$ (serum, 4) and $5.5 \pm 1.9 \mu \mathrm{g} / \mathrm{l}$ (serum, 5). A good correlation between the present method and a TRFIA described earlier by us (1) was found (data not shown). Likewise, measurements by the present method correlated very well $(r=0.95)$ with those obtained from the same normal and pathological serum samples by a method using a polyclonal sheep antibody both as the catching and detecting antibody in a solid-phase TR-FIA (present study).

In summary, we describe a new monoclonal antibody 2E1 to human pancreatic secretory phospholipase $A_{2}$ showing no cross-reactivity with other human tissues or ascitic phospholipase $A_{2}$. A specific TR-FIA method was developed to measure pancreatic phospholipase $A_{2}$ in serum samples.

\section{Acknowledgement}

The authors thank Ms Sinikka Kollanus and Ms Tuula Manninen for technical assistance, Mr Jaakko Liippo for photography, Dr Juha Grönroos for serum samples and Dr Vesa Kleimola for fruitful discussions.

\section{References}

1. Eskola, J. U., Nevalainen, T. J. \& Lövgren, T. N.-E. (1983) Time-resolved fluoroimmunoassay of human pancreatic phospholipase $\mathrm{A}_{2}$. Clin. Chem. 29, 1777-1780.

2. Nishijima, J., Okamoto, M., Ogawa, M., Kasaki, G. \& Yamano, T. (1983) Purification and characterization of human pancreatic phospholipase $\mathrm{A}_{2}$ and development of a radioimmunoassày. J. Biochem. 94, 137-147.

3. Sternby, B. \& Åerström, B. (1984) Immunoreactive pancreatic colipase, lipase and phospholipase $A_{2}$ in human plasma and urine from healthy individuals. Biochim. Biophys. Acta 789, 164-169.

4. Oka, Y., Ogawa, M., Matsuda, Y., Murata, A., Nishijima, J., Miyauchi, K., Uda, K., Yasuḍa, T. \& Mori, T. (1990) Serum immunoreactive pancreatic phospholipase $A_{2}$ in patients with various malignant tumours. Enzyme 43, 80-88.

5. Nevalainen, T. J., Eskola, J. U., Aho, A. J., Havia, V. T., Lövgren, T. N.-E. \& Näntö, V. (1985) Immunoreactive phospholipase $A_{2}$ in serum in acute pancreatitis and pancreatic cancer. Clin. Chem. 31, 1116-1120:

6. Büchler, M., Malfertheiner, P., Schädlich, H., Nevalainen, T., Mavromatis, T. \& Beger, H. G. (1989) Prognostic value of serum phospholipase $A_{2}$ in acute pancreatitis. Klin. Wochenschr. 67, 186-189:

7. Kortesuo, P. T. \& Nevalainen, T. J. (1991) Phospholipase $A_{2}$ in human ascitic fluid: purification, characterization and immunochemical detection. Biochem. J. 278, 263-267.

8. Eskola, J. U., Nevalainen, T. J. \& Aho, H. J. (1983) Purification and characterization of human pancreatic phospholipase $A_{2}$. Clin. Chem. 29, 1772-1776.

9. Galfre, G. \& Milstein, C. (1981) Preparation of monoclonal antibodies: strategies and procedures. Methods Enzymol. $73,3-46$.

10. Hemmilä, I., Dakubu, S., Mukkala, V-M., Siitari, H. \& Lövgren, T. (1984) Europium as a label in time-resolved immunofluorometric assays. Anal. Biochem. 137, 335343.

11. International Federation of Clinical Chemistry (1987) Approved recommendation (1987) on the theory of reference values. Part 5 . Statistical treatment of collected reference values. Determinations of reference limits. J. Clin. Chem. Clin. Biochem. 25, 645-656.

12. van den Bosch, H. (1980) Intracellular phospholipases A. Biochim. Biophys. Acta 604, 191-246.

13. van den Bosch, H. (1982) Phospholipases. In: New Comprehensive Biochemistry, vol. 4 (Hawthorne, J. N. \& Ansell, G. B., eds), pp. 313-357 Elsevier, Amsterdam. 
14. Gonzalez-Buritica, H., Smith, D. M. \& Turner, R. A. (1989) Characterization of soluble and cell associated phospholipase $A_{2}$ from rheumatoid synovial fluid. Ann. Rheum. Dis. $48,557-564$.

15. Ono, T., Tojo, H., Kuramitsu, S., Kagamiyama, H. Okamoto, M. (1988) Purification and characterization of a membrane-associated phospholipase $A_{2}$ from rat spleen. J. Biol. Chem. 263, 5732-5738.

16. Meijer, H., Meddens, M. J. M., Dijkman, R., Slotboom, A. J. \& de Haas, G. H. (1978) Immunological studies on pancreatic phospholipase $\mathrm{A}_{2}$. J. Biol. Chem. 253, 85648569.

17. Wurl, M. \& Kunze, H. (1985) Purification and properties of phospholipase $A_{2}$ from human seminal plasma. Biochim. Biophys. Acta 834, 411 - 418 .

18. Okamoto, M., Onto, T., Tojo, H. \& Yamano, T. (1985) Immunochemical relatedness between secretory phospholipase $A_{2}$ and intracellular phospholipase $A_{2}$. Biochim. Biophys. Res. Commun. 128, 788-794.
19. de Jong, J. G. N., Amesz, H., Aarsman, A. J., Lenting, H. B. M. \& van den Bosch, $H$. (1987) Monoclonal antibodies against an intracellular phospholipase $\mathrm{A}_{2}$ from rat liver and their cross-reactivity with other phospholipase $A_{2}$. Eur. J. Biochem. 164, 129-135.

20. Mollier, P., Chwetzoff, S. \& Ménez, A. A. (1990) A monòclonal antibody recognizing conserved epitope in a group of phospholipase $\mathrm{A}_{2}$. Mol. Immunol. 27, 7-15.

21. Masliah, J., Kadir, C., Pepin, D.,. Rybkine, T., Etienne, J., Chambaz, J. \& Bereziat, G. (1987) Antigenic relatedness between phospholipase $A_{2}$ from Naja naja venom and from mammalian cells. FEBS Lett. 222, 11-16.

22. Ono, T., Tojo, H., Inoue, K., Kagamiyama, H., Yamano, T. \& Okamoto, M. (1984) Rat pancreatic phospholipase $\mathrm{A}_{2}$ : purification, characterization, and $\mathrm{N}$-terminal amino acid sequence. J. Biochem. 96, 785-792.

23. Nevalainen, T. J. (1988) Phospholipase $A_{2}$ in acute pancreatitis. Scand. J. Gastroenterol. 23, 897-904.
Dr. Timo Nevalainen
Department of Pathology
Kiinamyllynkatu 10
SF-20520 Turku 